\title{
Analisis Penyerapan Tenaga Kerja pada Sektor Pariwisata (Sektor Perdagangan, Hotel dan Restoran) Di Kabupaten Badung
}

\author{
Safira Devi Rachmania, Niniek Imaningsih, Riko Setya Wijaya \\ Fakultas Ekonomi dan Bisnis Universitas Pembangunan Nasional "Veteran" Jawa Timur \\ Correspondence email: 17011010102@student.upnjatim.ac.id
}

\begin{abstract}
Abstrak. Tujuan penelitian ini untuk membuktikan adanya pengaruh jumlah kunjungan wisatawan mancanegara, jumlah kunjungan wisatawan domestik, tingkat hunian hotel, upah minimum dan inflasi terhadap penyerapan tenaga kerja pada sektor pariwisata di Kabupaten Badung. Penelitian ini menggunakan data sekunder atau time series dengan kurun waktu selama 16 tahun yaitu periode 2004-2019. Teknik analisis data yang digunakan adalah analisis regresi linier berganda dengan menggunakan spss 16.0. Berdasarkan hasil analisis menunjukan bahwa secara bersama-sama jumlah kunjungan wisatawan mancanegara, jumlah kunjungan wisatawan domestik, tingkat hunian hotel, upah minimum dan inflasi berpengaruh positif signifikan terhadap penyerapan tenaga kerja. Secara parsial kunjungan wisatawan mancanegara dan upah minimum berpengaruh signifikan terhadap penyerapan tenaga kerja, tingkat hunian hotel berpengaruh negatif siginifikan terhadap penyerapan tenaga kerja sedangkan jumlah kunjungan wisatawan domestik dan inflasi tidak berpengaruh signifikan terhadap penyerapan tenaga kerja pada sektor pariwisata di Kabupaten Badung. Variasi variabel jumlah kunjungan wisatawan mancanegara, jumlah kunjungan wisatawan domestik, tingkat hunian hotel, upah minimum dan inflasi dapat menjelaskan variasi penyerapan tenaga kerja sebesar 95 persen dan sebesar 5 persen dijelaskan oleh variabel lain di luar penelitian ini.
\end{abstract}

Kata Kunci: Penyerapan Tenaga Kerja, Jumlah Kunjungan Wisatawan Mancanegara, Jumlah Kunjungan Wisatawan Domestik, Tingkat Hunian Hotel, Upah Minimum, Inflasi.

\begin{abstract}
The purpose of this research to prove the existence of the influence of the number of foreign tourists visit, the number of domestic tourists visit, hotel occupancy rate, the minimum wage and inflation on employment in the tourism sector in Badung Regency. This research used secondary data or time series for 16 years namely the period 2004-2019. The data analysis technique used is multiple linear regression analysis using spss 16.0. Based on the results of the analysis show that the number of foreign tourist visits, the number of domestic tourist visit, hotel occupancy rates, the minimum wage and inflation simultaneously have a significant positive effect on employment. Partially the number of foreign tourist visits and the minimum wage affect employment in the tourism sector, hotel occupancy rates has negative and significant effect on employment while the number of domestic tourists visit and inflation does not affect employment in the tourism sector in Badung Regency. Variations in the number of foreign tourists visit, the number of domestic tourists visit, hotel occupancy rate, the minimum wage and inflation can explain variations in employment in the tourism sector by 95 percent and by 5 percent explained by other variables outside of this study.
\end{abstract}

Keywords: Employment, The Number of Foreign Tourists Visit, The Number of Domestic Tourists Visit, Hotel Occupancy Rates, The Minimum Wage, Inflation.

\section{PENDAHULUAN}

Berdasarkan hasil Survei Penduduk Antar Sensus (SUPAS) tahun 2015 (dalam Kusnandar, 2020) Indonesia berada dalam era bonus demografi, di mana penduduk usia produktif jumlahnya lebih besar dibanding penduduk tidak produktif. Hal ini dapat menjadi acuan bagi pemerintah Indonesia untuk lebih mengoptimalkan perluasan kesempatan kerja bagi masyarakat.

Upaya meningkatkan penyerapan tenaga kerja dapat dilakukan melalui pengembangan sektor-sektor lapangan usaha yang terdapat di Indonesia. Sektor pariwisata dapat dikatakan sebagai sektor yang siap dalam penyerapan tenaga kerja karena selain dapat menciptakan lapangan pekerjaan baru, juga dapat menghidupkan atau menyerap tenaga kerja yang berada di sekitar tempat wisata. (Ramdhan, 2018)

Dari sekian banyak wilayah di Indonesia, Bali menjadi salah satu tujuan wisata populer yang wajib dikunjungi wisatawan mancanegara maupun nusantara.
Provinsi Bali terbagi atas 8 wilayah Kabupaten dan Kota Denpasar sebagai ibukota Provinsi. Diantara kedelapan Kabupaten tersebut Kabupaten Badung merupakan pintu gerbang udara sekaligus pusat pariwisata, serta memiliki wilayah dengan jumlah kunjungan wisatawan terbanyak di Provinsi Bali. PDRB Kabupaten Badung pada sektor pariwisata berkontribusi paling besar yaitu 28,67 persen dari total PDRB Kabupaten Badung pada tahun 2019. Kabupaten Badung merupakan salah satu kabupaten yang melaksanakan otonomi daerah serta merupakan penyumbang terbesar kue ekonomi di Provinsi Bali dan mampu berperan dalam menyumbang hampir seperempat dari keseluruhan ekonomi yang dihasilkan di Provinsi Bali. (Wiguna dan Budhi, 2019) yaitu sebesar 22,94 persen.

Kegiatan pariwisata akan menimbulkan demand akan barang dan jasa yang akan merangsang pertumbuhan produksi khusunya di sektor perdagangan, hotel dan restoran yang berbasis padat karya sehingga 
mampu mengurangi pengangguran serta meningkatkan pendapatan dan taraf hidup masyarakat.

Banyaknya wisatawan mancanegara dan domestik yang datang dan menginap di Kabupaten Badung berdampak pada semakin banyaknya sarana dan prasarana penunjang seperti penginapan dan tempattempat hiburan yang didirikan untuk meningkatkan kepariwisataan.

Dalam melakukan perjalanan, wisatawan memiliki salah satu kebutuhan pokok yaitu kebutuhan akan sarana akomodasi yang memadai. Oleh karena itu, hotel menjadi peranan penting sebagai suatu bentuk akomodasi sehingga industri pariwisata berperan besar dalam munculnya bisnis perhotelan.

Tingkat hunian hotel merupakan suatu keadaan sampai sejauh mana jumlah kamar terjual, jika diperbandingkan dengan seluruh jumlah kamar yang mampu untuk dijual (Hanggara, 2009). Meningkatnya hunian hotel diharapkan dapat menyerap tenaga kerja bagi masyarakat, khususnya masyarakat yang bertempat tinggal atau bermukim di sekitar daerah pariwisata.

Penyerapan tenaga kerja pada dasarnya dipengaruhi oleh faktor internal dan eksternal. Secara internal meningkatnya jumlah penduduk yang bekerja dipengaruhi oleh besar kecilnya pertumbuhan upah minimum yang telah ditentukan. Upah Minimum yang ditetapkan di Kabupaten Badung mengalami peningkatan setiap tahunnya dari tahun 2004 sampai pada tahun 2019.

Selanjutnya penyerapan tenaga kerja dipengaruhi oleh faktor eksternal yaitu inflasi. Menurut Nanga (2005, p. 248) apabila inflasi yang terjadi masih tergolong ringan, maka perusahaaan akan menambah jumlah output atau produksi yang tentu juga dibarengi oleh pertambahan faktor-faktor produksi seperti tenaga kerja. Tetapi apabila tingkat inflasi tidak terkendali maka akan mengurangi tingkat produktivitas perusahaan sehingga berdampak pada berkurangnya jumlah penyerapan tenaga kerja.

Jumlah tenaga kerja yang terserap pada lapangan usaha sektor pariwisata di Kabupaten Badung pada tahun 2004-2006 mengalami peningkatan signifikan, sedangkan pada tahun 2007-2009 mengalami penurunan. Selanjutnya pada tahun 2010 jumlah tenaga kerja sektor pariwisata mulai mengalami peningkatan yang cukup signifikan tetapi hingga pada tahun 2015 jumlahnya mengalami fluktuasi. Pada tahun 2016 jumlah tenaga kerja di sektor pariwisata kembali mengalami penurunan kemudian pada tahun 2017 mengalami kenaikan yaitu sebesar 140.335 jiwa dan kembali mengalami penurunan pada tahun 2018 sebesar 138.047 jiwa. Setelah itu pada tahun 2019 jumlahnya kembali mengalami kenaikan. Meskipun jumlah penyerapan tenaga kerja sektor pariwisatanya mengalami fluktuasi, namun cenderung mengalami peningkatan yang cukup signifikan.
Kondisi penyerapan tenaga kerja sektor pariwisata di Kabupaten Badung termasuk cukup tinggi dibandingkan dengan wilayah lain di Provinsi Bali, namun jumlah per tahunnya yang mengalami fluktuasi menjadi ketertarikan tersendiri untuk dijadikan sebagai bahan penelitian. Serta perlu adanya penelitian lebih lanjut mengenai peran jumlah kunjungan wisatawan mancanegara, wisatawan domestik, tingkat hunian hotel, upah minimum dan tingkat inflasi terhadap penyerapan tenaga kerja sektor pariwisata di Kabupaten Badung yang dapat digunakan sebagai rumusan masalah. Sedangkan tujuan penelitian untuk mengetahui apakah terdapat adanya pengaruh dari masing-masing variabel terhadap penyerapan tenaga kerja sektor pariwisata di Kabupaten Badung.

\section{Kajian Pustaka \\ Tenaga Kerja}

Berdasarkan Undang-Undang No. 13 tahun 2003 mengenai ketenagakerjaan dijelaskan bahwa tenaga kerja merupakan setiap orang yang mampu melakukan pekerjaan guna menghasilkan barang atau jasa, baik untuk memenuhi kebutuhan hidup sendiri maupun masyarakat. Penduduk yang dapat digolongkan ke dalam kategori tenaga kerja yaitu apabila telah memasuki usia kerja. Tenaga kerja dapat dibagi dalam dua kelompok. Menurut Pujoalwanto (2014, p. 215) secara garis besar yaitu tenaga kerja dan bukan tenaga kerja. Tenaga kerja menurut Undang-Undang Nomor 13 Tahun 2003 adalah mereka yang bekerja dalam usia 15 sampai dengan 64 tahun. Sedangkan bukan tenaga kerja, merupakan penduduk yang berusia dibawah 15 tahun dan di atas 64 tahun. Adalah orang-orang yang tidak dapat bekerja atau tidak mampu atau tidak berkeinginan untuk bekerja meskipun terdapat adanya kesempatan kerja.

Adapun juga Teori Permintaan Tenaga Kerja yang merupakan hubungan antar tingkat upah yang ditentukan oleh perusahaan dan kuantitas tenaga kerja yang diminta oleh perusahaan tersebut. Adapun faktor-faktor yang dapat mempengaruhi permintaan tenaga kerja yaitu perubahan tingkat upah dan faktor lain-lain.

\section{Pariwisata}

Menurut UU RI No.10 tahun 2009 pasal 1 ayat 3 tentang kepariwisataan, berbunyi "pariwisata adalah berbagai macam kegiatan wisata dan didukun berbagai fasilitas serta layanan yang disediakan oleh masyarakat, pengusaha, pemerintah, dan pemerintah daerah".

Menurut Goeldner \& Ritchie (2009) pariwisata adalah rangkaian dari kegiatan, layanan dan industri yang memberikan pengalaman perjalanan, yang terdiri dari akomodasi, tempat makan, hiburan, toko, transportasi, layanan dan fasilitas kegiatan perhotelan yang disediakan bagi perorangan atau grup yang berpergian. Singkatnya pariwisata memberikan pelayanan akan kebutuhan dan keinginan wisatawan. 
Pariwisata adalah perjalanan yang dilakukan untuk liburan ataupun rekreasi, dan juga persiapan yang dilakukan untuk aktivitas tersebut. Seiring dengan perkembangan zaman, pariwisata menjadi sebuah mega bisnis yang keuntungannya sangat menjanjikan. Ribuan bahkan jutaan orang mengeluarkan dana yang cukup besar, untuk sementara meninggalkan rumah dan pekerjaan demi memuaskan atau membahagiakan diri (pleasure) dan menghabiskan waktu luang (leisure). Pariwisata menjadi suatu gaya hidup dan bagian penting di negara-negara maju. Berkaitan dengan itu, seorang merkantilisme yang bernama Thomas Mun dalam bukunya yang berjudul Navigation Act berpendapat bahwa sektor pariwisata adalah kegiatan yang sangat penting sebagai sumber penerimaan bagi pengusaha yang menyediakan jasa perjalanan, termasuk penginapan dan rumah makan sejak tahun 1960.

Pariwisata sebagai suatu konsep dapat dipandang dari berbagai perspektif yang berbeda. Salah satu perspektif mengenai pariwisata adalah suatu kegiatan melakukan perjalanan dari rumah untuk tujuan usaha atau bersantai. Perspektif lainnya mengenai pariwisata ialah suatu bisnis dalam penyediaan barang dan jasa bagi wisatawan dan dalam perjalanannya menyangkut setiap pengeluaran oleh atau untuk wisatawan atau pengunjung. Serta perspektif mengenai kepariwisataan merupakan suatu lingkup usaha yang meliputi komponen usaha yang jumlahnya ratusan, mulai dari usaha kecil hingga usaha besar.

\section{Wisatawan}

Pacific Area Travel Association (dalam Suwena dan Widyatmaja, 2017, p. 40) berpendapat bahwa wisatawan adalah orang-orang yang sedang mengadakan perjalanan dalam jangka waktu 24 jam dan maksimal 3 bulan di dalam suatu negara yang bukan negara di mana biasanya ia tinggal. Menurut Soekadijo (dalam Hutasoit, 2017) wisatawan adalah pengunjung yang mengunjungi suatu Negara lalu setidak-tidaknya tinggal 24 jam.

Menurut Pendit (dalam Nugraha, 2018) wisatawan dapat dibedakan menjadi dua kategori yaitu wisatawan internasional dan nasional. Wisatawan Internasional (Mancanegara) adalah orang yang sedang melakukan perjalanan wisata diluar negeri asalnya dan wisatawan dari negara lain yang sedang berwisata didalam negerinya. Wisatawan Nasional (Domestik) adalah penduduk Indonesia yang melakukan perjalanan diluar tempatnya berdomisili tetapi tetap di wilayah Indonesia, sekurang-kurangya dalam jangka waktu 24 jam atau menginap kecuali kegiatan tersebut mendatangkan nafkah di tempat yang dikunjungi.

\section{Tingkat Hunian Hotel}

Tingkat hunian hotel merupakan suatu kondisi sejauh mana jumlah kamar hotel yang terjual. Menurut
Damardjati (2006, p. 121) tingkat hunian kamar adalah jumlah kamar yang terisi atau disewakan kepada tamu dan dibandingkan dengan seluruh jumlah kamar yang tersedia, diperhitungkan dalam jangka waktu harian, bulanan atau tahunan. Tingkat hunian hotel bergantung pada bagaimana fasilitas dan pelayanan yang diberikan, semakin baik pelayanan dan lengkapnya fasilitas yang disediakan pihak hotel maka akan meningkatkan jumlah pengunjung yang datang serta memunculkan keinginan untuk tinggal lebih lama karena merasa aman dan nyaman. Semakin banyak jumlah wisatawan yang diikuti dengan lamanya waktu tinggal di suatu daerah tujuan wisata tentunya akan membawa dampak positif terhadap tingkat hunian kamar hotel. Metode perhitungan tingkat hunian kamar pada sebuah hotel umumnya diukur secara presentase yaitu membandingkan jumlah kamar yang terisi dengan jumlah kamar yang tersedia pada periode tertentu.

Semakin banyak kamar hotel yang terjual, maka akan berpengaruh pada semakin tingginya pendapatan yang akan diterima oleh pihak pengelola hotel tersebut. Selain itu melalui pajak hotel akan meningkatkan perekonomian daerah tersebut. Dengan pengembangan yang baik, maka akan meningkatkan pendapatan daerah dan pendapatan masyarakat melalui penyerapan tenaga kerja serta perluasan usaha.

\section{Upah Minimum}

Berdasarkan ketentuan Pasal 1 ayat 30 UndangUndang No. 13 Tahun 2003, upah adalah hak pekerja atau buruh yang diterima dan dinyatakan dalam bentuk uang sebagai imbalan dari pengusaha atau pemberi kerja kepada pekerja atau buruh yang ditetapkan dan dibayarkan menurut suatu perjanjian kerja, kesepakatan atau peraturan perundang-undangan, termasuk tunjungan bagi pekerja atau buruh dan keluarganya atas suatu pekerjaan atau jasa yang telah dan akan dilakukan. Dalam melakukan penetapan besarnya upah pengusaha tidak boleh memberikan upah yang jumlahnya lebih rendah dari ketentuan upah minimum yang telah ditetapkan pemerintah setempat (Pasal 90 ayat $1 \mathrm{UU}$ No.13/ 2003). Apabila pengusaha melakukan hal tersebut maka kesepakatan atau kontrak mengenai pembayaran upah akan batal menurut hukum (Pasal 91 ayat 2 UU No. 13/2003).

Hak untuk menerima upah pada pekerja yang telah bekerja paling rendah selama 7 jam sehari atau 40 jam dalam 1 minggu adalah upah minimum atau upah minimum sektoral yang oleh pemerintah telah ditetapkan dan berlaku pada daerah yang telah ditentukan, terkecuali terdapat izin penangguhan pelaksanaan pemberian upah minimum oleh perusahaan.

\section{Inflasi}

Inflasi merupakan suatu keadaan dimana hargaharga mengalami kenaikan secara tajam (absolute) dan 
berlangsung terus menerus dalam jangka waktu cukup lama. Definisi inflasi diartikan beragam seperti yang dapat ditemukan dalam literatur ekonomi. Keanekaragaman definisi tersebut terjadi akibat luasnya pengaruh inflasi terhadap berbagai sektor perekonomian.

Hubungan yang erat dan luas antara inflasi dan berbagai sektor perekonomian tersebut melahirkan berbagai perbedaan pengertian dan persepsi tentang inflasi, demikian pula dalam memformulasi kebijakan untuk solusinya. Prinsipnya masih terdapat beberapa kesatuan pandangan bahwa inflasi merupakan suatu fenomena dan dilema ekonomi.

Definisi inflasi menurut beberapa penulis dalam literatur ekonomi antara lain:

a. Inflasi adalah suatu proses kenaikan harga-harga yang berlaku dalam suatu perekonomian. (Sukirno, 2013, p. 14)

b. Inflasi merupakan kondisi kenaikan harga barang dan jasa secara umum dan terus menerus. (Suparmono, 2004, p. 128)

c. Inflasi adalah suatu kondisi dimana tingkat harga (agregat) mengalami peningkatan secara terusmenerus dan mempengaruhi individu, dunia usaha dan pemerintah. (Puspopranoto, 2004, p. 38)

\section{METODE}

\section{Jenis Penelitian}

Jenis data yang digunakan dalam penelitian ini adalah data sekunder atau kuantitatif. Data diperoleh berdasarkan data yang tersedia dan dipublikasikan oleh Badan Pusat Statistik Indonesia dan Kabupaten Badung. Jenis data yang digunakan adalah Time series tahun 2004-2019. Beberapa data yang digunakan dalam melakukan penelitian ini, yaitu:

1. Data Jumlah Kunjungan Wisatawan Mancanegara di Kabupaten Badung Tahun 2004-2019

2. Data Jumlah Kunjungan Wisatawan Domestik di Kabupaten Badung Tahun 2004-2019

3. Data Tingkat Hunian Hotel di Kabupaten Badung Tahun 2004-2019

4. Data Upah Minimum di Kabupaten Badung Tahun 2004-2019

5. Data Inflasi di Indonesia Tahun 2004-2019

\section{Tempat dan Waktu Penelitian}

Tempat penelitian ini adalah Kabupaten Badung yang merupakan salah satu kabupaten yang melaksanakan otonomi daerah serta merupakan penyumbang terbesar kue ekonomi di Provinsi Bali dan mampu berperan dalam menyumbang hampir seperempat dari keseluruhan ekonomi yang dihasilkan di Provinsi Bali.

Penelitian ini dilakukan dalam kurun waktu 16 tahun, yakni pada tahun 2004 sampai dengan tahun 2019.

\section{Metode Analisis}

Penelitian berikut ini dilakukan dengan menggunakan metode analisis kuantitatif yaitu dengan menggunakan alat analisis berupa metode regresi linear berganda. Sedangkan proses dalam pengolahan data dilakukan dengan menggunakan program spss 16.0 sebagai alat dalam mengolah data.

\section{Analisis Regresi Berganda}

Analisis regresi berganda merupakan studi ketergantungan antara satu variabel yaitu variabel tidak bebas (dependent variable), terhadap satu atau lebih variabel, yaitu variabel yang bersifat menerangkan, dengan tujuan untuk memperkirakan dan meramalkan nilai rata-rata dari variabel tidak bebas jika nilai variabel yang menerangkan sudah diketahui. Variabel yang menerangkan biasa disebut dengan variabel bebas (independent variable). Model analisis regresi berganda sebagai berikut:

$\mathrm{Y}=\mathrm{f}(\mathrm{X} 1, \mathrm{X} 2, \mathrm{X} 3, \mathrm{X} 4, \mathrm{X} 5)$

Selanjutnya dibentuk dalam model ekonometrika dengan persamaan sebagai berikut:

$Y=\alpha+\beta_{1} X_{1}+\beta_{2} X_{2}+\beta_{3} X_{3}+\beta_{4} X_{4}+\beta_{5} X_{5}+e$

Dimana:

$\mathrm{Y}=$ jumlah tenaga kerja sektor pariwisata

$\mathrm{X}_{1}=$ jumlah kunjungan wisatawan mancanegara

$\mathrm{X}_{2}=$ jumlah kunjungan wisatawan domestik

$\mathrm{X}_{3}=$ tingkat hunian hotel

$\mathrm{X}_{4}=$ upah minimum

$\mathrm{X}_{5}=$ inflasi

$\beta 0=$ konstanta

$\beta 1,2, \mathrm{n}=$ koefisien regresi

$\mathrm{e}=$ variabel pengganggu

\section{HASIL DAN PEMBAHASAN}

Hasil Analisis Regresi Linier Berganda

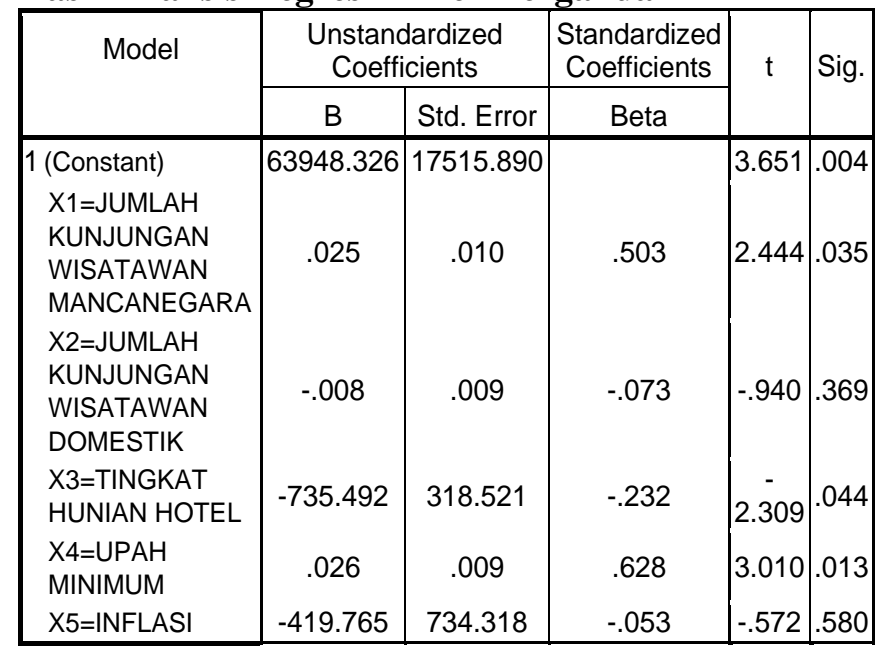

a. Dependent Variable: $Y=$ TENAGA KERJA SEKTOR PARIWISATA 
Safira Devi Rachmania, Niniek Imaningsih dan Riko Setya Wijaya, Analisis Penyerapan Tenaga Kerja pada Sektor Pariwisata (Sektor Perdagangan, Hotel dan Restoran) Di Kabupaten Badung

Berikut hasil regresi untuk mengetahui pengaruh Jumlah Kunjungan Wisatawan Mancanegara $\left(\mathrm{X}_{1}\right)$, Jumlah Kunjungan Wisatawan Domestik $\left(\mathrm{X}_{2}\right)$, Tingkat Hunian Hotel $\left(\mathrm{X}_{3}\right)$ Upah Minimum $\left(\mathrm{X}_{4}\right)$ dan Inflasi $\left(\mathrm{X}_{5}\right)$ terhadap Penyerapan Tenaga Kerja pada Sektor Pariwisata (Y). Hasil regresi bisa dilihat pada tabel berikut:

Sumber: Output SPSS 16.0

\section{Uji Asumsi Klasik}

\section{Uji Autokorelasi}

Model Summaryb

\begin{tabular}{|l|c|c|r|r|r|}
\hline $\begin{array}{l}\text { Mod } \\
\text { el }\end{array}$ & $\mathrm{R}$ & $\begin{array}{c}\mathrm{R} \\
\text { Squar } \\
\mathrm{e}\end{array}$ & $\begin{array}{c}\text { Adjusted } \\
\text { R Square }\end{array}$ & $\begin{array}{c}\text { Std. Error } \\
\text { of the } \\
\text { Estimate }\end{array}$ & $\begin{array}{r}\text { Durbin- } \\
\text { Watson }\end{array}$ \\
\hline 1 & $.976^{\mathrm{a}}$ & .953 & .930 & 8046.891 & 2.212 \\
\hline
\end{tabular}

a. Predictors: (Constant), X5 = INFLASI, X2 = JUMLAH KUNJUNGAN WISATAWAN

DOMESTIK, X1 = JUMLAH KUNJUNGAN

WISATAWAN MANCANEGARA, X3 = TINGKAT

HUNIAN HOTEL, X4 = UPAH MINIMUM

b. Dependent Variable: $Y=$ TENAGA KERJA SEKTOR PARIWISATA

Sumber: Output SPSS 16.0

Berdasarkan hasil output diatas, diketahui nilai DW sebesar 2,212, hasil nilai DW lebih besar dari nilai $\mathrm{dU}$ yaitu 2,212>2,1567 maka tidak terdapat autokorelasi positif. Sedangkan pada deteksi autokorelasi negatif apabila nilai $\mathrm{dL}<(4-\mathrm{dW})<\mathrm{dU}$ yaitu $0,6150<1,788<2,1567$ maka pengujian tidak meyakinkan atau tidak dapat disimpulkan (berada di daerah keraguan).

\section{Uji Multikolinieritas}

\begin{tabular}{|c|c|c|c|c|c|}
\hline Variabel & Tolerance & Ketentuan & VIF & Ketentuan & Keterangan \\
\hline $\mathrm{X}_{1}$ & 0,111 & $>0,10$ & 9,023 & $<10$ & $\begin{array}{c}\text { Tidak Terjadi } \\
\text { Multikolinear }\end{array}$ \\
\hline $\mathrm{X}_{2}$ & 0,777 & $>0,10$ & 1,286 & $<10$ & $\begin{array}{c}\text { Tidak Terjadi } \\
\text { Multikolinear }\end{array}$ \\
\hline $\mathrm{X}_{3}$ & 0,467 & $>0,10$ & 2,142 & $<10$ & $\begin{array}{c}\text { Tidak Terjadi } \\
\text { Multikolinear }\end{array}$ \\
\hline $\mathrm{X}_{4}$ & 0,108 & $>0,10$ & 9,276 & $<10$ & $\begin{array}{c}\text { Tidak Terjadi } \\
\text { Multikolinear }\end{array}$ \\
\hline $\mathrm{X}_{5}$ & 0,545 & $>0,10$ & 1,836 & $<10$ & $\begin{array}{c}\text { Tidak Terjadi } \\
\text { Multikolinear }\end{array}$ \\
\hline
\end{tabular}

Sumber: Output SPSS 16.0

Hasil uji multikolinearitas di atas, nilai VIF yang di dapat $>10$ sehingga dapat disimpulkan bahwa tidak terdapat masalah multikolinearitas.

\section{Uji Heteroskedastisitas}

\begin{tabular}{|c|c|c|c|c|c|}
\hline \multicolumn{6}{|c|}{ Coefficients $^{a}$} \\
\hline \multirow[t]{2}{*}{ Model } & \multicolumn{2}{|c|}{$\begin{array}{l}\text { Unstandardized } \\
\text { Coefficients }\end{array}$} & \begin{tabular}{|c|} 
Standa \\
rdized \\
Coeffic \\
ients
\end{tabular} & \multirow[t]{2}{*}{$\mathrm{t}$} & \multirow[t]{2}{*}{ Sig. } \\
\hline & B & Std. Error & Beta & & \\
\hline 1 (Constant) & 5493.986 & 10243.778 & & .536 & .603 \\
\hline $\begin{array}{l}\text { X1 = JUMLAH } \\
\text { KUNJUNGAN } \\
\text { WISATAWAN } \\
\text { MANCANEGARA }\end{array}$ & .000 & .006 & .028 & .031 & .976 \\
\hline $\begin{array}{l}\text { X2 = JUMLAH } \\
\text { KUNJUNGAN } \\
\text { WISATAWAN } \\
\text { DOMESTIK }\end{array}$ & -.003 & .005 & -.240 & -.695 & .503 \\
\hline $\begin{array}{l}\text { X3 = TINGKAT } \\
\text { HUNIAN HOTEL }\end{array}$ & -7.349 & 186.280 & -.018 & -.039 & .969 \\
\hline $\begin{array}{l}\text { X4 = UPAH } \\
\text { MINIMUM }\end{array}$ & .001 & .005 & .194 & .209 & .838 \\
\hline$X 5=I N F L A S I$ & -51.224 & 429.449 & -.049 & -.119 & .907 \\
\hline
\end{tabular}

a. Dependent Variable:

Abs_RES

Sumber: Output SPSS 16.0

Berdasarkan tabel diatas, diperoleh tingkat signifikansi koefisien korelasi dengan metode Glejser dengan keseluruhan residualnya lebih besar dari 0,05 (tidak signifikan). Hal tersebut menunjukkan bahwa antara nilai residual dengan variabel yang menjelaskan tidak mempunyai korelasi yang berarti. Jadi dapat disimpulkan persamaan tersebut tidak terjadi heteroskedastisitas.

\section{Uji Koefisien Determinasi $\mathbf{R}^{2}$}

\begin{tabular}{|c|c|c|}
\hline $\begin{array}{l}\text { Variabel } \\
\text { Terikat }\end{array}$ & $\begin{array}{l}\text { Variabel } \\
\text { Bebas }\end{array}$ & $\begin{array}{c}\text { Koefisien } \\
\text { Determinasi }\end{array}$ \\
\hline \multirow{5}{*}{$\begin{array}{c}\text { Penyerapan } \\
\text { Tenaga } \\
\text { Kerja Sektor } \\
\text { Pariwisata }\end{array}$} & $\begin{array}{c}\text { Jumlah } \\
\text { Kunjungan } \\
\text { Wisatawan } \\
\text { Mancanegara }\end{array}$ & \multirow{5}{*}{0,953} \\
\hline & $\begin{array}{c}\text { Jumlah } \\
\text { Kunjungan } \\
\text { Wisatawan } \\
\text { Domestik }\end{array}$ & \\
\hline & $\begin{array}{c}\text { Tingkat } \\
\text { Hunian Hotel }\end{array}$ & \\
\hline & $\begin{array}{c}\text { Upah } \\
\text { Minimum }\end{array}$ & \\
\hline & Inflasi & \\
\hline
\end{tabular}

$\mathrm{R}^{2}=$ Koefisien determinasi sebesar 0,953 artinya 95,3\% dari seluruh pengamatan menunjukkan variabel bebas Jumlah Kunjungan Wisatawan Mancanegara $\left(\mathrm{X}_{1}\right)$, 
Jumlah Kunjungan Wisatawan Domestik $\left(\mathrm{X}_{2}\right)$, Tingkat Hunian Hotel $\left(\mathrm{X}_{3}\right)$, Upah Minimum $\left(\mathrm{X}_{4}\right)$ dan Inflasi $\left(\mathrm{X}_{5}\right)$ mampu menjelaskan variasi variabel terikatnya yaitu Penyerapan Tenaga Kerja pada Sektor Pariwisata (Y), sisanya 4,7\% (diperoleh dari 100\% - 95,3\%) adalah dipengaruhi faktor lain yang tidak tampak pada model atau galatnya.

\section{Uji Simultan (Uji f)}

\begin{tabular}{|c|c|c|c|c|c|c|}
\hline \multicolumn{7}{|c|}{ ANOVA } \\
\hline Mo & & Sum of Squares & df & Mean Square & $\mathrm{F}$ & Sig. \\
\hline \multirow[t]{3}{*}{1} & Regression & 1.314E10 & 5 & 2.627E9 & 40.573 & $.000^{\circ}$ \\
\hline & Residual & $6.475 \mathrm{E} 8$ & 10 & $6.475 \mathrm{E} 7$ & & \\
\hline & Total & $1.378 \mathrm{E} 10$ & 15 & & & \\
\hline
\end{tabular}

a. Predictors: (Constant), X5 = INFLASI, X2 = JUMLAH KUNJUNGAN WISATAWAN DOMESTIK, X1 = JUMLAH KUNJUNGAN WISATAWAN MANCANEGARA, X3 = TINGKAT HUNIAN HOTEL, X4 = UPAH MINIMUM

b. Dependent Variable: $Y=$ TENAGA KERJA SEKTOR PARIWISATA Sumber: Output SPSS 16.0

Pada tabel ANOVA persamaan I diperoleh nilai $F_{\text {hitung }}$ sebesar 40,573 dengan tingkat signifikasi sebesar $0,000^{\mathrm{a}}$, sedangkan nilai $\mathrm{F}_{\text {tabel }}(\alpha=0,05)$ dengan degree of freedom $\left(\mathrm{df}_{1}\right) 5$ (jumlah variabel bebas/k) dan $\mathrm{df}_{2} 10(\mathrm{n}$ $\mathrm{k}$-1) diperoleh nilai $\mathrm{F}$ tabel sebesar 3,33. Dari hasil tersebut diketahui bahwa nilai $F_{\text {hitung }} \geq F_{\text {tabel. }}$. Maka dapat disimpulkan secara simultan variabel Jumlah Kunjungan Wisatawan Mancanegara $\left(\mathrm{X}_{1}\right)$, Jumlah Kunjungan Wisatawan Domestik $\left(\mathrm{X}_{2}\right)$, Tingkat Hunian Hotel $\left(\mathrm{X}_{3}\right)$, Upah Minimum $\left(\mathrm{X}_{4}\right)$ dan Inflasi $\left(\mathrm{X}_{5}\right)$ berpengaruh secara signifikan dan positif terhadap Penyerapan Tenaga Kerja pada Sektor Pariwisata (Y).

\section{Uji Parsial (Uji t)}

\begin{tabular}{|c|c|c|c|}
\hline Variabel & T Hitung & T Tabel & Sig. \\
\hline $\begin{array}{c}\text { Jumlah Kunjungan } \\
\text { Wisatawan Mancanegara }\left(\mathrm{X}_{1}\right)\end{array}$ & 2,444 & 2,22814 & 0,035 \\
\hline $\begin{array}{c}\text { Jumlah Kunjungan } \\
\text { Wisatawan Domestik }\left(\mathrm{X}_{2}\right)\end{array}$ & $-0,940$ & $-2,22814$ & 0,369 \\
\hline $\begin{array}{c}\text { Tingkat Hunian Hotel }\left(\mathrm{X}_{3}\right) \\
\text { Upah Minimum }\left(\mathrm{X}_{4}\right)\end{array}$ & $-2,309$ & $-2,22814$ & 0,044 \\
\hline Inflasi $\left(\mathrm{X}_{5}\right)$ & $-0,572$ & $-2,22814$ & 0,580 \\
\hline
\end{tabular}

Sumber: Output SPSS 16.0

1. Jumlah Kunjungan Wisatawan Mancanegara $\left(\mathrm{X}_{1}\right)$ Dari perhitungan secara parsial diperoleh nilai $\mathrm{t}$ hitung sebesar 2,444 sedangkan nilai $t$ tabel $(\alpha / 2=$ $0,025)$ dengan degree of freedom (df) 10 (n-k-1) diperoleh nilai t tabel sebesar 2,22814. Dari hasil tersebut dapat diketahui bahwa nilai $t_{\text {hitung }} 2,444>t_{\text {tabel }}$ 2,22814. Maka dapat disimpulkan bahwa jumlah kunjungan wisatawan mancanegara secara parsial berpengaruh positif dan signifikan terhadap penyerapan tenaga kerja pada sektor pariwisata di Kabupaten Badung.

2. Jumlah Kunjungan Wisatawan Domestik $\left(\mathrm{X}_{2}\right)$

Dari perhitungan secara parsial diperoleh nilai $t$ hitung sebesar $-0,940$ sedangkan nilai $\mathrm{t}$ tabel $(\alpha / 2=$ $0,025)$ dengan degree of freedom (df) 10 (n-k-1) diperoleh nilai t tabel sebesar-2,22814. Dari hasil tersebut dapat diketahui bahwa nilai thitung $-0,940<$ $\mathrm{t}_{\text {tabel }}-2,22814$. Maka dapat disimpulkan bahwa jumlah kunjungan wisatawan domestik secara parsial tidak berpengaruh signifikan terhadap penyerapan tenaga kerja pada sektor pariwisata di Kabupaten Badung.

3. Tingkat Hunian Hotel $\left(\mathrm{X}_{3}\right)$

Dari perhitungan secara parsial diperoleh nilai $\mathrm{t}$ hitung sebesar $-2,309$ sedangkan nilai $\mathrm{t}$ tabel $(\alpha / 2=$ $0,025)$ dengan degree of freedom (df) 10 (n-k-1) diperoleh nilai t tabel sebesar -2,22814. Dari hasil tersebut dapat diketahui bahwa nilai $t_{\text {hitung }}-2,309>$ $\mathrm{t}_{\text {tabel }}-2,22814$. Maka dapat disimpulkan bahwa tingkat hunian hotel secara parsial berpengaruh negatif dan signifikan terhadap penyerapan tenaga kerja pada sektor pariwisata di Kabupaten Badung.

4. Upah Minimum $\left(\mathrm{X}_{4}\right)$

Dari perhitungan secara parsial diperoleh nilai $t$ hitung sebesar 3,010 sedangkan nilai t tabel $(\alpha / 2=$ $0,025)$ dengan degree of freedom (df) 10 (n-k-1) diperoleh nilai t tabel sebesar 2,22814. Dari hasil tersebut dapat diketahui bahwa nilai $t_{\text {hitung }} 3,010>t_{\text {tabel }}$ 2,22814. Maka dapat disimpulkan bahwa upah minimum secara parsial berpengaruh positif dan signifikan terhadap penyerapan tenaga kerja pada sektor pariwisata di Kabupaten Badung.

5. Inflasi $\left(\mathrm{X}_{5}\right)$

Dari perhitungan secara parsial diperoleh nilai $\mathrm{t}$ hitung sebesar $-0,572$ sedangkan nilai $t$ tabel $(\alpha / 2=$ $0,025)$ dengan degree of freedom (df) 10 (n-k-1) diperoleh nilai t tabel sebesar -2,22814. Dari hasil tersebut dapat diketahui bahwa nilai thitung $-0,572<$ $\mathrm{t}_{\text {tabel }}-2,22814$. Maka dapat disimpulkan bahwa inflasi secara parsial tidak berpengaruh signifikan terhadap penyerapan tenaga kerja pada sektor pariwisata di Kabupaten Badung.

\section{SIMPULAN}

Berdasarkan analisis yang telah diuraikan pada bab sebelumnya maka dapat diambil kesimpulan sebagai berikut:

1. Berdasarkan hasil analisis dan pembahasan yang telah dilakukan menunjukkan bahwa variabel Jumlah Kunjungan Wisatawan Mancanegara, Jumlah Kunjungan Wisatawan Domestik, Tingkat Hunian 
Hotel, Upah Minimum dan Inflasi berpengaruh secara simultan dan nyata terhadap Penyerapan Tenaga Kerja pada Sektor Pariwisata (Sektor Perdagangan, Hotel dan Restoran) di Kabupaten Badung.

2. Variabel Jumlah Kunjungan Wisatawan Mancanegara secara parsial berpengaruh positif dan signifikan terhadap Penyerapan Tenaga Kerja pada Sektor Pariwisata di Kabupaten Badung. Hal tersebut dikarenakan meningkatnya jumlah wisatawan mancanegara akan menimbulkan adanya gejala konsumtif untuk produk-produk yang ada di daerah tujuan wisata serta menarik datangnya investor untuk berinvestasi dalam pembangunan sarana dan prasarana baru sehingga dibutuhkannya tenaga kerja tambahan untuk memenuhi permintaan dan melayani kebutuhan wisatawan mancanegara yang berkunjung.

3. Variabel Jumlah Kunjungan Wisatawan Domestik secara parsial tidak berpengaruh signifikan terhadap Penyerapan Tenaga Kerja pada Sektor Pariwisata di Kabupaten Badung. Hal tersebut dikarenakan wisatawan domestik yang berkunjung hanya melakukan perjalanan singkat rata-rata dua hari satu malam dan tidak terlalu banyak menggunakan jasa usaha pariwisata yang terdapat di Kabupaten Badung.

4. Variabel Tingkat Hunian Hotel secara parsial berpengaruh negatif dan signifikan terhadap Penyerapan Tenaga Kerja pada Sektor Pariwisata di Kabupaten Badung. Hal tersebut dikarenakan meningkatnya tingkat hunian hotel hanya mempengaruhi jumlah produksi (pendapatan yang diperoleh hotel) dan tidak meningkatkan penyerapan tenaga kerja.

5. Variabel Upah Minimum secara parsial berpengaruh positif dan signifikan terhadap Penyerapan Tenaga Kerja pada Sektor Pariwisata di Kabupaten Badung. Hal tersebut dikarenakan Pada kondisi tertentu seperti pada saat kondisi masih kurangnya tenaga kerja disuatu perusahaan tertentu maka untuk menarik para tenaga kerja dilakukan dengan menaikkan upah tetapi, pada saat perusahaan tersebut telah merasa karyawannya cukup maka pada saat itu upah kembali dinormalkan.

6. Variabel Inflasi secara parsial tidak berpengaruh signifikan terhadap Penyerapan Tenaga Kerja pada Sektor Pariwisata di Kabupaten Badung. Hal tersebut dikarenakan rata-rata inflasi yang terjadi di Indonesia periode 2004-2019 tergolong inflasi ringan yaitu $6,14 \%$ yang tidak langsung mempengaruhi efisiensi dalam produktivitas serta banyaknya jumlah pengeluaran yang tetap dibelanjakan wisatawan di perjalanan saat berwisata sehingga tidak memiliki pengaruh tehadap kepariwisataan di Kabupaten Badung.

Keadaan tersebut berimplikasi terhadap perlunya

Pemerintah Kabupaten Badung selaku pengambil kebijakan agar lebih mempromosikan daerah pariwisatanya melalui berbagai media digital baik dalam maupun luar negeri, agar dapat meningkatkan daya tarik wisatawan asing maupun domestik. Peranan stakeholder lainnya juga sangat diperlukan dalam menggali potensi wisata yang dapat memunculkan destinasi wisata baru sehingga meningkatkan pembangunan daerah di Kabupaten Badung serta menarik datangnya investor untuk berinvestasi dan meningkatkan perekonomian di sekitar wilayah Kabupaten Badung.

\section{Saran}

Berdasarkan kesimpulan di atas, maka berikut ini beberapa saran sebagai bahan pertimbangan sebagai berikut:

1. Untuk terus meningkatkan Jumlah Kunjungan Wisatawan Mancanegara, baik dari pihak pemerintah Kabupaten Badung maupun swasta diharapkan dapat terus melaksanakan program peningkatan fasilitas objek pariwisata secara berkala serta meningkatkan pembangunan infrastruktur jalan dengan melakukan pelebaran jalan raya untuk mengurangi kemacetan lalu lintas demi kenyamanan wisatawan. Selain itu menggali potensi destinasi-destinasi wisata baru yang belum dikenal oleh publik terutamanya destinasi alam di wilayah Badung bagian utara sehingga pembangunan daerah di Kabupaten Badung bisa lebih merata.

2. Wisatawan Domestik merupakan pangsa pasar yang sangat potensial dan patut diperhitungkan. Apabila diperhatikan secara lebih serius, peluang dan manfaat ekonomi pasar wisatawan domestik tidak kalah dengan pasar wisatawan mancanegara, mengingat total populasi penduduk Indonesia sekitar 270 juta dan sekitar 53,34\% dari mereka melakukan perjalanan wisata. Untuk mendukung pengembangan pasar wisatawan domestik adalah ketersediaan informasi mengenai karakteristik wisatawan domestik yang lebih terpercaya dan memadai serta diperlukan strategi pemasaran seperti melalui media online yang memudahkan wisatawan dalam mengakses informasi agar dapat meningkatkan daya tarik wisatawan domestik. Selain itu diharapkan adanya sentra wisata kuliner halal agar wisatawan domestik yang mayoritas muslim merasa lebih nyaman saat berkuliner di wilayah Kabupaten Badung.

3. Bagi pihak perhotelan, sebaiknya juga ikut serta berupaya untuk meningkatkan penyerapan tenaga kerja dengan bekerja sama dengan Sekolah Menengah Kejuruan Perhotelan di Kabupaten Badung dan pihak-pihak terkait untuk mendapat tenaga kerja yang berkualitas dan ahli di bidang perhotelan untuk menjaga kualitas pelayanan agar wisatawan yang berkunjung merasa nyaman dan merasa ingin kembali berkunjung ke Kabupaten Badung. 
4. Bagi peneliti selanjutnya diharapkan menambah variabel - variabel lain diluar variabel dalam penelitian ini dan menggunakan periode data yang lebih panjang dan terbaru sehingga diperoleh hasil yang lebih representatif dan dapat memberikan hasil yang maksimal untuk menjelaskan hal-hal yang mempengaruhi penyerapan tenaga kerja pada sektor pariwisata di Kabupaten Badung sehingga dapat bermanfaat sebagai masukan bagi pihak-pihak terkait dalam meningkatkan penyerapan tenaga kerja pada sektor pariwisata di Kabupaten Badung.

\section{DAFTAR PUSTAKA}

Damardjati, R. S. (2006) 'Istilah-istilah Dunia Pariwisata'. Jakarta: PT. Pradnya Paramitha.

Goeldner, C. R. and Ritchie., J. R. B. (2009) 'Tourism: Principles, Practices, PhilosophIes'.

Hanggara, V. (2009) 'Pengertian Tingkat Hunian Hotel'. Diakses pada 11 December 2020.http://vickyhanggara.blogspot.com/2009/05/ pengertian-tingkat-hunian-kamarhotel.html.

Hutasoit, N. (2017) 'Pengaruh Jumlah Kunjungan Wisatawan Mancanegara dan Jumlah Hunian Hotel Terhadap Penerimaan Sub Sektor PDRB Industri Pariwisata di Provinsi Sumatera Utara Tahun 2004-2013', JOM Fekon, Vol.4 No.1.

Kusnandar, V. B. (2020) 'Inilah Proyeksi Jumlah Penduduk Indonesia 2020'. Diakses pada 16 November

2020https://databoks.katadata.co.id/datapublish/20 20/01/02/inilah-proyeksi-jumlah-pendudukindonesia-2020.

Nanga, M. (2005) 'Makro Ekonomi: Teori, Masalah, dan Kebijakan'. Jakarta: PT Grafindo Persada.

Nugraha, B. F. (2019) 'Belanja Wisatawan Asal Singapura dan Malaysia di Kota Bandung', Jurnal Pariwisata Universitas Pasundan, Vol 6, No 2, pp. 147-153.

Pujoalwanto, B. (2014) 'Perekonomian Indonesia: Tinjauan Historis, Teoritis dan Empiris'. Yogyakarta: Graha Ilmu.

Puspopranoto, S. (2004) 'Keuangan Perbankan dan Pasar Keuangan'. Jakarta: Pustaka LP3ES Indonesia.

Ramdhan, M. (2018) 'Analisis Penyerapan Tenaga Kerja Pada Sektor Pariwisata di Kabupaten/Kota Daerah Istimewa Yogyakarta Tahun 2011-2015' (Skripsi). Universitas Islam Indonesia.

Sukirno, S. (2013) Makro Ekonomi, Teori Pengantar. Jakarta: PT. Raja Grafindo Persada.

Suparmono (2004) 'Pengantar Ekonomika Makro: Teori, Soal dan Penyelesaiannya'. Yogyakarta: UPP AMP YKPN.

Suwena, I. K. and Widyatmaja, I. G. N. (2017) 'Pengetahuan Dasar Ilmu Pariwisata'. Cetakan Ed. Denpasar: Pustaka Lasaran.
Wiguna, I. M. G. S. and Budhi, M. K. S. (2019) 'Analisis Sektor Unggulan dan Potensi Pertumbuhan Ekonomi di Kabupaten Badung Tahun 2012-2016', E-Jurnal EP Unud, pp. 810841. 